\title{
Assessment of Vitamin D Role in Depression
}

\author{
SHAABAN R. HELAL, M.D.*; OMNIA A. MOHAMMED, M.D.*; AHMED A. ABD EL-RAHMAN, M.D.** and \\ EREEN S. KHALIL, M.Sc.* \\ The Departments of Clinical Pathology* and Psychiatry**, Faculty of Medicine, Assiut University, Assiut, Egypt
}

\begin{abstract}
Background: Depression is a devastating disease that adversely affects all aspects of one's existence. There is some evidence that low circulating concentration of serum 25 hydroxyvitamin D [25(OH)D], the marker for Vitamin D status, is associated with mood disorders, including major depresssive disorder.
\end{abstract}

Aim of Study: The aim of this work is to investigate the association between serum Vitamin D concentrations and depression and to evaluate the correlation between the concentrations of Vitamin D and severity of depression.

Subjects and Methods: This study was conducted on 66 patients suffering from depression, and 22 apparently healthy individuals as controls. Complete psychiatric interview; with application of Beck Depression Inventory II (BDI-II) Scale for diagnosis and assessment of the severity of depression was done. Laboratory investigations including kidney function tests, liver function tests,serum total calcium,phosphorus and serum Vitamin D (25-OH Vitamin D3/D2) was done for all subjects.

Results: 21,23 and 22 patients had mild, moderate and severe depression respectively. There was statistically very high significant decrease in Vitamin D level in patients group compared to control group. In patients group, $40.9 \%$ of patients had Vitamin D deficiency (serum 25(OH]D $<12 \mathrm{ng} / \mathrm{mL}$ ), 33.3\% had Vitamin D insufficiency (serum 25(OH]D ranged from 12 to $20 \mathrm{ng} / \mathrm{mL}$ ), and $25.8 \%$ had sufficient level of Vitamin D (serum $25(\mathrm{OH}] \mathrm{D}>20 \mathrm{ng} / \mathrm{mL}$ ). There was statistically significant decrease of Vitamin D levels in female patients group compared to male patients group. There was statistically significant negative correlation between BDI-II score and Vitamin D level in patients group.

Conclusion: The finding of this study revealed evidence of an association between low $25(\mathrm{OH}) \mathrm{D}$, a marker of Vitamin $\mathrm{D}$ status, and depression, suggesting a direct effect of Vitamin $\mathrm{D}$ on development of depression. There was an association between low Vitamin D status and the severity of depression.Vitamin D deficiency was more pronounced in female patients than male patients.

Key Words: Depression - Vitamin D - Depression severity Beck depression inventory scale.

Correspondence to: Dr. Ereen S. Khalil Takawy, E-Mail: ereensamir88@gmail.com

\section{Introduction}

DEPRESSION is a common illness worldwide and it results from a complex interaction between social, psychological, and biological factors [1]. It is an etiologically heterogenous group of brain disorders characterized by a wide range of symptoms that reflect alteration in cognitive, psychomotor and emotional process [2]. Depression is a common mental disorder that affects both males and females in every age group and is found across cultures. An investigation into the global burden of disease found depressive disorders to be the second leading cause of disability worldwide [3] Vitamin D (D represents D2, D3, or both), known as the "sunshine vitamin," and is a secosterol produced endogenously in the skin from sun exposure or obtained from foods [4]. It is necessary for essential biological functions such as bone and mineral metabolism, muscle function, psychological function and immunity [5]. There is accumulating evidence of the association of serum $(25(\mathrm{OH}) \mathrm{D})$ levels with a wide range of physiological outcomes such as bone health, cardiovascular diseases, diabetes,hypertension, metabolic syndrome, and cancer [6]. Vitamin D receptors are present in many different types of cells, including neurons and glial cells. Most importantly, Vitamin D is accepted for its neurosteroid activity and impact on brain serotonin (a neurotransmitter critical to emotional health), suggesting a possible role in mood regulation [7]. Vitamin D is also involved in numerous brain processes including neuroimmunomodulation, regulation of neurotrophic factors, neuroprotection, neuroplasticity and brain development making it biologically plausible that Vitamin D might be associated with depression [8]

\section{Material and Methods}

Study design: This is a hospital based prospective study. 
Study area: The study was conducted at Psychiatry Department, Assiut University. The study was done in the Clinical Pathology Department of Assiut University Hospital in the years from 2015 to 2016 .

Study populations: There were two groups of participants in this study. Group 1 (case group): Comprised 66 patients suffering from depression recruited from Psychiatry Department, Assiut University. Group 2 (control group): 22 normal subjects. These were age and sex matched with the test group.

Sample size: A total of 88 subjects were studied. These included 66 patients suffering from depression (case group) and 22, age and sex matched normal subjects (control group).

Ethical approval: All subjects were informed about the aim of the study and gave their consent.

All patients were subjected to personal and psychiatric history and complete medical examination:

To assess the severity of depression, the 21Beck Depression Invenrory Scale for DepressionII (BDI-II) was used [9]. The severity of depression was categorized to mild, moderate and severe according to age and gender.

\begin{tabular}{lcccc}
\hline Age & $\begin{array}{c}\text { No or } \\
\text { minimal } \\
\text { depression }\end{array}$ & $\begin{array}{c}\text { Mild } \\
\text { depression }\end{array}$ & $\begin{array}{c}\text { Moderate } \\
\text { depression }\end{array}$ & $\begin{array}{c}\text { Severe } \\
\text { depression }\end{array}$ \\
Female (18-21) yrs & $0-20$ & $21-29$ & $30-37$ & $38-63$ \\
Male (18-21) yrs & $0-19$ & $20-27$ & $28-34$ & $35-63$ \\
Female (22-60) yrs & $0-20$ & $21-31$ & $32-41$ & $42-63$ \\
Male (22-60) yrs & $0-15$ & $16-24$ & $25-33$ & $34-63$ \\
\hline
\end{tabular}

Mild depression: Twenty one (21) patients, ten were females and eleven were males.

Moderate depression: Twenty three (23) patients, seventeen were females and six were males.

Severe depression: Twenty two (22) patients, ten were females and twelve were males.

\section{Exclusion criteria:}

Patients with (liver, kidney diseases, GIT problems as Crohn's disease and malabsorption, patients on anticonvulsant drugs, pregnant and lactating females, psychiatric disorders other than depression or those with comorbid diagnosis).

\section{Procedure:}

Sample collection and storage: Five ml were collected into plain tube. Blood was allowed to clot for 15 minutes at $37^{\circ} \mathrm{C}$ and sera were separated by centrifugation at $3000 \mathrm{rpm}$ for 10 minutes. The separated sera were inspected to ensure that they were clear and non-hemolyzed or lipaemic. Serum was divided into two aliquots, one aliquot was used for determination of the routine laboratory investigations and the other aliquot was stored at $-20^{\circ} \mathrm{C}$ till time of assay. Liver function tests, kidney fnction tests, total calcium, phosphorus and serum Vitamin D level was done.

\section{Laboratory assays:}

1- Routine investigations: Serum Liver function tests, kidney function tests, total calcium and phosphorus (for patients and controls): They were performed on auto analyzer Modular (Roche) USA.

2- Specific tests: Vitamin D level (for patients and controls): Was done on Alegria ${ }^{\circledR}$ (ORGENTEC Diagnostic GmbH-Germany), using 25-OH Vitamin D3/D2-ORG 270Orgentec-Germany). The determination of 25-OH Vitamin D2/D3 is based on competitive Enzyme Linked Immunosorbent Assay (ELISA). Serum 25(OH) D levels of $<12$ $\mathrm{ng} / \mathrm{ml}$ was defined as deficient, $12-20 \mathrm{ng} / \mathrm{ml}$ as insufficient and $>20 \mathrm{ng} / \mathrm{ml}$ as sufficient Vitamin D.

\section{Statistical analysis:}

Data collected and analyzed by computer program SPSS" Ver. 21" Chicago. USA. Data expressed as mean, Standard deviation and number, percentage. ANOVA test Chi. Square was used to determine significance for categorical variable. Person's correlation to determine significance between variables in same group.

\section{Results}

This study included 88 participant, 66 patients suffering from depression (their age ranged from 18-50 years ( 37 were females and 29 were males) and 22 healthy individuals as control their age ranged from 22-51 years (15 females and 7 males). There were no statistically significant difference regarding age and sex (Table 1). There was also no statistically significant difference according kidney function, liver function,total calcium and phosphorus. In patients group there were $31.8 \%$ of patients had mild depression, $34.8 \%$ had moderate depression and $33.3 \%$ had severe depression (Table 2).

There was statistically very high significant decrease in Vitamin D level in patients group compared to control group $(p<0.000)$ (Table (3) and Fig. (1). 
Table (1): Age and sex of patients and control groups.

\begin{tabular}{|c|c|c|c|}
\hline Item & $\begin{array}{c}\text { Patients group } \\
n=66\end{array}$ & $\begin{array}{c}\text { Control group } \\
\mathrm{n}=22\end{array}$ & $\begin{array}{c}p- \\
\text { value }\end{array}$ \\
\hline \multicolumn{4}{|l|}{ 1-Age: Years: } \\
\hline Range & $(18.0-50.0)$ & $(22.0-51.0)$ & $p=0.91$ \\
\hline Mean \pm SD & $33.1 \pm 13.0$ & $32.8 \pm 6.7$ & $\mathrm{n} . \mathrm{s}$ \\
\hline \multicolumn{4}{|l|}{ 2- Sex: } \\
\hline Female & $37(56.1 \%)$ & $15(68.2 \%)$ & $p=0.22$ \\
\hline Male & $29(43.9 \%)$ & $7 \quad(31.8 \%)$ & n.s \\
\hline
\end{tabular}

Table (2): Distribution of levels of depression in patients group.

\begin{tabular}{lccc}
\hline \multirow{2}{*}{ Item } & \multicolumn{3}{c}{ Levels of depression } \\
\cline { 2 - 4 } & $\begin{array}{c}\text { Mild } \\
\mathrm{n}=21\end{array}$ & $\begin{array}{c}\text { Moderate } \\
\mathrm{n}=23\end{array}$ & $\begin{array}{c}\text { Severe } \\
\mathrm{n}=22\end{array}$ \\
\hline Percentage & $31.8 \%$ & $34.8 \%$ & $33.3 \%$ \\
BDI score & $17-31$ & $26-40$ & $43-61$ \\
\hline
\end{tabular}

Table (3): Vitamin D in patients and control groups.

\begin{tabular}{llcc}
\hline Item & $\begin{array}{c}\text { Control group } \\
\mathrm{n}=22\end{array}$ & $\begin{array}{c}\text { Patients group } \\
\mathrm{n}=66\end{array}$ & $\begin{array}{c}p \text { - } \\
\text { value }\end{array}$ \\
\hline Vitamin D: $n g / m l:$ & & & \\
$\quad$ Range & $(20.60-42.50)$ & $(5.0-39.4)$ & $p<0.000^{* * *}$ \\
$\quad$ Mean $\pm \mathrm{SD}$ & $26.86 \pm 5.81$ & $15.12 \pm 7.50$ & \\
\hline
\end{tabular}

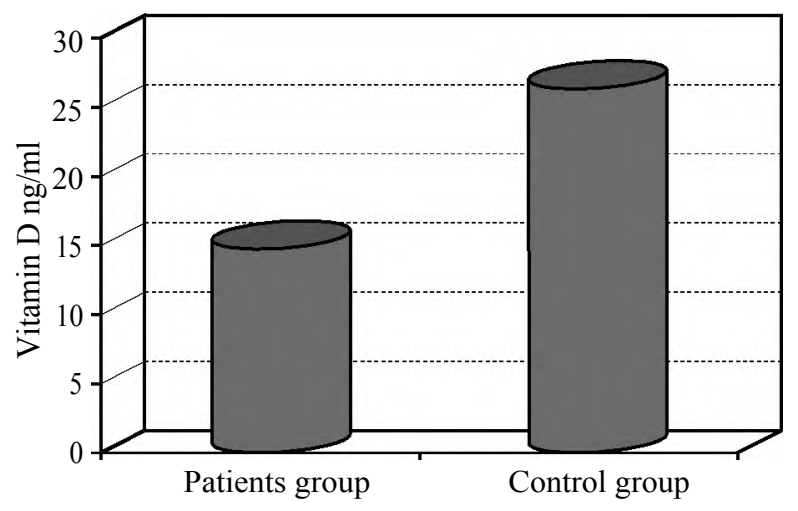

Fig. (1): Vitamin D in patients and control groups.

Table (4) illustrated distribuation of Vitamin D levels in patients group, $40.9 \%$ of patients had Vitamin D deficiency (serum 25(OH]D $<12 \mathrm{ng} / \mathrm{mL}$ ), $33.3 \%$ had Vitamin D insufficiency (serum $25(\mathrm{OH}]$ $\mathrm{D}$ ranged from 12 to $20 \mathrm{ng} / \mathrm{mL}$ ), and $25.8 \%$ had sufficient level of Vitamin D (serum 25(OH]D $>20$ $\mathrm{ng} / \mathrm{mL}$ ). Table (5) illustrated range and mean values of serum Vitamin D in females and males patient groups with different levels of Vitamin D. The mean value of Vitamin $\mathrm{D}$ in female patients was decreased than male patients, this decrease was statistically significant $(p<0.01)$. This decrease was also statistically significant in sufficient group of Vitamin D $(p<0.001)$. Female patients showed insignificant decrease of Vitamin D level in both deficient and insufficient groups of Vitamin D levels $(p=0.40, p=0.30$ ) respectively.

Table (4): Distribuation of Vitamin D in patients group.

\begin{tabular}{ll}
\hline Item & Patients group \\
\hline Vitamin D: & \\
Deficient: $<12 \mathrm{ng} / \mathrm{ml}$ & $27(40.9 \%)$ \\
Insufficient: $12-20 \mathrm{ng} / \mathrm{ml}$ & $22(33.3 \%)$ \\
Sufficient: $>20 \mathrm{ng} / \mathrm{ml}$ & $17(25.8 \%)$ \\
\hline
\end{tabular}

Table (5): Vitamin D levels in females and males patients groups.

\begin{tabular}{|c|c|c|c|}
\hline Item & $\begin{array}{c}\text { Females } \\
n=37\end{array}$ & $\begin{array}{c}\text { Males } \\
\mathrm{n}=29\end{array}$ & $\begin{array}{c}p- \\
\text { value }\end{array}$ \\
\hline \multicolumn{4}{|c|}{ Vitamin D: $n g / m l:$} \\
\hline Range & $5-23.9$ & $5-39.4$ & \\
\hline Mean \pm SD & $13.40 \pm 5.53$ & $17.85 \pm 8.82$ & $p<0.01 *$ \\
\hline \multicolumn{4}{|c|}{ Deficient: $<12 \mathrm{ng} / \mathrm{ml}$ : } \\
\hline Range & $(5.0-11.3)$ & $(5.0-11.4)$ & \\
\hline Mean \pm SD & $8.73 \pm 2.85$ & $9.42 \pm 4.22$ & $p=0.40 \mathrm{~ns}$ \\
\hline \multicolumn{4}{|c|}{ Insufficient: $12-20 \mathrm{ng} / \mathrm{ml}$ : } \\
\hline Range & $(12.0-18.8)$ & $(12.5-19.1)$ & \\
\hline Mean \pm SD & $15.45 \pm 2.35$ & $16.05 \pm 2.29$ & $p=0.30 \mathrm{~ns}$ \\
\hline \multicolumn{4}{|c|}{ Sufficient: > 20ng/ml: } \\
\hline Range & $(20.3-24.0)$ & $(20.4-39.4)$ & \\
\hline Mean \pm SD & $22.02 \pm 1.78$ & $26.13 \pm 6.70$ & $p<0.001 * *$ \\
\hline
\end{tabular}

Table (6) and Fig. (2) illustrated serum Vitamin $\mathrm{D}$ and levels of depression in patients group. There was statistically high significant difference between the three groups $(p<0.000)$. There was statistically significant decrease of Vitamin D level in patients with moderate and severe level of depression compared to patients with mild depression $(p 1<0.000$, $p 2<0.000)$ respectively, and also there was statistically significant decrease of Vitamin D level in patients with severe depression compared to patients with moderate depression $(p 3<0.000)$.

Table (6): Serum Vitamin D and levels of depression in patients group.

\begin{tabular}{lcccc}
\hline & \multicolumn{3}{c}{ Levels of depression } & \\
\cline { 2 - 4 } Item & $\begin{array}{c}\text { Mild } \\
\mathrm{n}=21\end{array}$ & $\begin{array}{c}\text { Moderate } \\
\mathrm{n}=23\end{array}$ & $\begin{array}{c}\text { Severe } \\
\mathrm{n}=22\end{array}$ & $\begin{array}{c}p \text { value } \\
\text { Vitamin D: }\end{array}$ \\
$n$ ng/ml: & & & & $\begin{array}{c}p<0.000^{* * *} \\
p 1<0.000^{* * *}\end{array}$ \\
Range & $(12.0-39.4)$ & $(5.4-20.9)$ & $(5.0-18.8)$ & $p 2<0.000^{* * *}$ \\
Mean $\pm \mathrm{SD}$ & $22.33 \pm 7.19$ & $13.69 \pm 4.11$ & $9.73 \pm 4.60$ & $p 3<0.000^{* * *}$ \\
\hline
\end{tabular}

p1: Moderate versus mild.

p2: Severe versus mild.

p3: Severe versus moderate. 


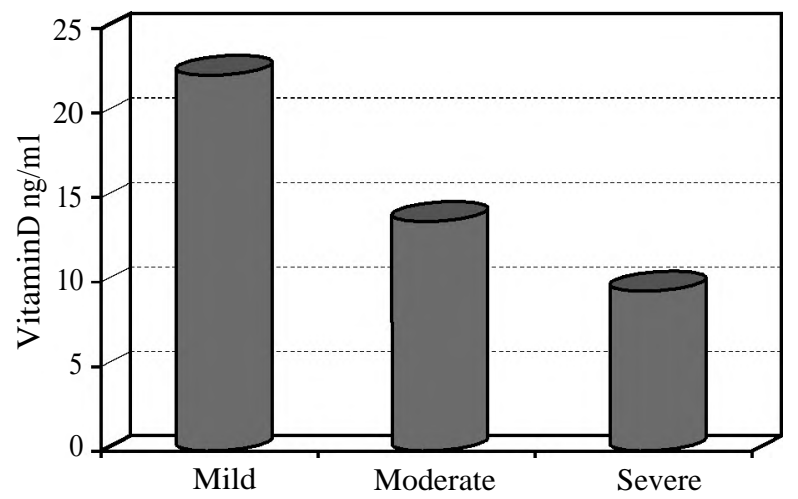

Fig. (2): Serum Vitamin D and levels of depression in patients group.

Correlation between Vitamin D and BDI score in patients group illustrated in Fig. (3). There was statistically significant negative correlation $(r=-.784, p<0.000)$ between BDI score and Vitamin $\mathrm{D}$ in patients group Fig. (3).

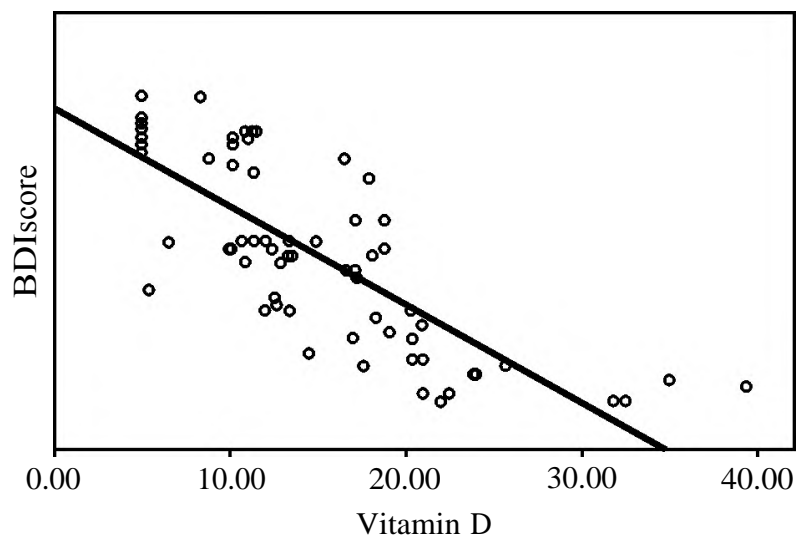

Fig. (3): Correlation between Vitamin D and BDI score in patients group.

\section{Discussion}

Depression is associated with significant disability, mortality and healthcare costs. It is the third leading cause of disability in high-income countries and affects approximately 840 million people worldwide. Although biological, psychological and environmental theories have been advanced, the underlying pathophysiology of depression remains unknown and it is probable that several different mechanisms are involved [10]

Vitamin D is involved in numerous brain processes which include neuroimmuno modulation, regulation of neurotrophic factors, neuroprotection, neuroplasticity and brain development [11], making it biologically plausible that this vitamin might be associated with depression [12].

Vitamin D deficiency has received increasing attention over the last decade, recently an interest in the potential role of Vitamin D in mental health has increased, and it has been suggested that depression is dependent on Vitamin D status. Vitamin $D$ receptors are widely distributed in areas of the human brain that are involved in depression [13] Vitamin D helps the brain produce serotonin, a neurotransmitter critical to emotional health [14]

This study was designed to determine Vitamin $D$ level in patients who have depression and correlate Vitamin D concentrations in serum with the severity of depression.

In this study the patients group included 66 patients, $37(56.1 \%)$ of them were females and 29 $(43.9 \%)$ of them were males. Hildebrandt et al., [15] found that the gender ratio was 2.3:1 (female: male). In a study by Dana-Alamdari et al. [8], they reported that the patients group included 44 personnel, $35(79.5 \%)$ were females and $9(20.5 \%)$ were males. Also Von Känel et al., [16] investigated 380 depressed patients with mean age $47 \pm 12$ years, $70 \%$ of them were women).

This appearance of gender variation in depression may be attributed to biological factors (e.g., genetics, neurotransmitters, and hormones) and victimization (e.g., childhood trauma, restrictive gender roles [17].

In the current study $18.2 \%$ of patients with age group from $18-21$ years old and $81.8 \%$ of patients with age group from 22-60 years old, this means that depression is most common among older adults. In a study done by Hussein et al., [14] on 50 Egyptian depressed females, they found that depression also affect older adults. This is also in agreement with Tsopelas et al., [18] who reported that depression is the most common mental illness in older adults, with concomitant effects on morbidity, mortality, and quality of life.

In the present study, the mean value of Vitamin D showed statistically high significant decrease in patients group when compared to control group. In the cohort study of Milaneschi et al., [19] which included older persons suggested that hypovitaminosis D is a risk factor for development of depressive symptoms. Also Jaddou et al., [6] in a national population-based household sample of 4,002 Jordanian participants, demonstrated a significant association between depression and low serum 25(OH) D level.

Kjaergaard et al., [20] evaluated Vitamin D deficiency and depression in a general population, and established that low serum 25-(OH)D levels were a significant predictor of depression. Also 
Milaneschi et al., [21] reported in a case control study included 1892 patients with history of current and remitted depression and 494 healthy subjects as a controls of age group from 18-65 years old. They found that low levels of $25(\mathrm{OH}) \mathrm{D}$ were associated to presence and severity of depressive disorders.

In another study done by Jorde et al., [22] found that a low serum 25-hydroxyvitamin $\mathrm{D}$ level is associated with development of depression. Von Känel et al., [16] found that Vitamin D deficiency was significantly associated with increased levels of depressive symptoms in patients hospitalized with a depressive episode.

Some authors have found that high-dose Vitamin D supplementation has a distinctive effect on depressive symptoms [23,24]

The role of Vitamin D in the development of depression can be explained by that Vitamin $\mathrm{D}$ Receptor (VDR) and Vitamin D activating enzyme, 1 -alpha-hydroxylase, are widely distributed in human brain, particularly in the hypothalamus and also in the limbic system, which is assumed to be involved in pathophysiology of the depression [25] One area where VDR and hydroxylases have been found is the amygdala, which is the center of the limbic system, where behavior and emotions are regulated [26].

Vitamin D stimulates the expression of nerve growth factor and promotes neuritogenesis [27] Several studies have shown that Vitamin D is involved in brain development and that its deficiency results in altered morphology (enlarged ventricles and reduced cortical thickness as it occurs in schizophrenia) and behavior in adulthood [28].Moreover, it has been shown that Vitamin D regulates gene expression of tyrosine hydroxylase, an essential enzyme involved in the synthesis of norepinephrine and dopamine, both neurotransmitters are involved in mood regulation and depression [29].

The immunomodulatory activity of Vitamin D has been related to inflammation that play a causal role in depression: Vitamin D has been shown to down-regulate inflammatory mediators, such as nuclear factor $\kappa \mathrm{B}$, which have been linked to sickness behavior, psychosocial stress, and depression [30].

In contrast to our findings Dana-Alamdari et al., [8] in a study done on Tabriz, Iran, they reported that Vitamin D deficiency was observed in $75 \%$ of depressed patients and $80.5 \%$ of healthy subjects with no statistically significant difference. This may be explained by that in this locality, there is limited exposure to UV due to lifestyle preferences, work schedule, and the fear of skin damage, skincovering clothes and sunscreens are effective barriers for adequate exposure to UV rays, which impedes production of Vitamin D in the skin. Hence, intake of Vitamin D from fortified food sources to achieve adequate levels of Vitamin D appear to be necessary $[8]$.

There are a number of possible reasons for the conflicting results among studies, including differences in population groups (i.e., ethnic and other cultural differences), age of the participants surveyed, measures of depression obtained, type of assay used for the analysis of serum Vitamin D, and statistical adjustment of known confounding factors including sun exposure [7]. Importantly, in a study by Nanri and colleagues (2009), the authors found an association between $25(\mathrm{OH}) \mathrm{D}$ and depression symptoms during winter, but not in summer or overall, thereby suggesting the season of study has a major influence on results [31].

In the current study, in patients group there was 27 patients (40.9\%) had Vitamin D deficiency, 22 patients $(33.3 \%)$ had Vitamin D insufficiency and 17 patients $(25.8 \%)$ had sufficient level of Vitamin D. This is in consistent with a study by Hussein et al., [14] that was done on 50 Egyptian depressed females, they found (38\%) of patients had Vitamin $\mathrm{D}$ deficiency, (46\%) had Vitamin D insufficiency and $(16 \%)$ had sufficient level of Vitamin D. The 25(OH)D levels was measured on a Chemiluminescence Analyzer which uses a 1-step assay [14]

Ganji et al., [27] found that in a study composed of 7970 depressed patients, Vitamin D deficiency (Vitamin D <20ng/ml) present in $24.7 \%$ of patients, Vitamin D insufficiency, (Vitamin D ranged from $20-30 \mathrm{ng} / \mathrm{ml}$ ) present in $29.6 \%$ of patients, Vitamin D sufficiency (Vitamin D $>30 \mathrm{ng} / \mathrm{ml}$ ) present in $45.7 \%$ of patients. However the large number of the study sample and the type of kit they used for Vitamin D analysis which was Radioimmunoassay (RIA) kit may be the cause of some differences in the results.

Also Von Känel et al., [16], they reported that Vitamin D deficiency were present in $55.5 \%$ of patients, Vitamin D insufficiency were present in $31.8 \%$ of patients and Vitamin D sufficiency were present in $12.6 \%$ of patients. The number of patients were 380 and they used two types of kits, the first was by certified commercial laboratories using liquid chromatography-mass spectrometry, and the second was an enzyme-linked fluorescent assay. 
In the current study, the mean value of Vitamin $D$ in female patients showed statistically significant decrease when compared to male patients. This is in agreement with Hoogendijk et al., [32], and Ganji et al., [27], who have found lower levels of Vitamin $\mathrm{D}$ in women.

Sex differences in the relationship between 25(OH)D and depression could be attributable to different factors. This may be due to lack of sun exposure and veiled clothing style in developing countries females [33] or may be due to prolonged breast feeding without Vitamin D supplementation in the Middle East [34] . In our study, weaker association between $25(\mathrm{OH}) \mathrm{D}$ and depression in men could be due to the smaller number of men with low levels of $25(\mathrm{OH}) \mathrm{D}$.

In the current study there was an association between lower $25(\mathrm{OH}) \mathrm{D}$ concentration and higher depression status with the lowest level of Vitamin $\mathrm{D}$ in severe level of depression and highest level in mild level of depression. This is in agreement with Hussein et al., [14] who reported that lower Vitamin D level was associated with more severe depression and as the level of Vitamin D level increase, not only associated with mild depression but also associated with a decreased risk for current depression and increased Vitamin D consumption elevates mood and promotes a positive outlook with statistical significant negative correlation between low Vitamin D and severity grading of depression [14].

Ganji et al., [27], found an association between lower $25(\mathrm{OH}) \mathrm{D}$ concentration and higher depression status and depression severity among a group of participants aged 15-39 years. In their study, depression status was assessed using the Diagnostic Interview Schedule (DIS) developed by the National Institute of Mental Health.

In contrast to our findings, Zhao et al., [35] utilizing the data reported in National Health and Nutritional Examination Survey (NHANES), found no significant association between serum concentrations of Vitamin D and the presence of major depression, minor depression, and moderate to severe depression. Pan et al., [36] also reported no significant association between Vitamin D status and depression in Chinese in older patients aged from 50-70 years.

In the current study, there was negative correlation between Beck Depression Inventory (BDIII) score and Vitamin D level ( $r=-.784, p=0.000$ ), as highest scores are associated with lowest levels of Vitamin D. This is in agreement with Lee et al.,
[37], in a study conducted on 432 men with depression using BDI score to evaluate the level of depression, they found that serum $25(\mathrm{OH}) \mathrm{D}$ levels were inversely associated with the BDI-II score $(r=0.19, p<0.001)$.

Also Sang-Hyun et al., [13], reported in their study that there was a significant negative correlation between the serum 25-OHD levels and the BDI-II score. In a study by Jorde et al., [23], found that those with insufficient $25(\mathrm{OH}) \mathrm{D}$ level had significantly higher total BDI scores than those with sufficient $25(\mathrm{OH}) \mathrm{D}$.

There are other studies using different scales to evaluate the level of depression. In a study done by Hoang et al., [38], and Hoogendijk et al., [32], they found that depression severity as measured by continuous Center for Epidemiologic Studies Depression Scale Score (CES-D) score was significantly associated with decreased 25(OH)D.

Also Polak et al., [7] found that serum 25(OH)D status was significantly negatively associated with the total CES-D scores. The study showed that for every one standard deviation increase in serum $25(\mathrm{OH}) \mathrm{D}(27 \mathrm{nmol} / \mathrm{L}$ or $10.8 \mathrm{ng} / \mathrm{ml})$, there was a 4.5 point decrease in the CES-D score among participants aged 17-25 years.

\section{Conclusions:}

The present study found evidence of an association between low 25(OH)D, a marker of Vitamin $\mathrm{D}$ status, and depression, suggesting a direct effect of Vitamin D on development of depression. There was an association between low Vitamin D status and the severity of depression. Vitamin D deficiency was more pronounced in female patients than male patients.

\section{Disclosure of conflict of interest:}

The authors state that they have no conflict of interest.

\section{References}

1- NEMAT S., FARHAD M. and MOHAMMAD R.T.: Vitamin D deficiency and Depression: Middle East J. Rehabil. Health, 2 (3): E26961, 2015.

2- ARYA A. and VERMA P.: A review on pathophysiology, classification and long term course of Depression. International Research Journal of Pharmacy, 3 (3):90-6, 2012.

3- FERRARI A.J., CHARLSON F.J., NORMANM R.E., et al.: Burden of depressive disorders by country, sex, age, and year: Findings from Global Burden of Disease Study 2010. The Lancet, 382 (9904): 1575-86, 2013.

4- EL-HAJJ FULEIHAN G.: Vitamin D deficiency in the Middle East and Its Health Consequences. In: Holick MF, 
editor. Vitamin D: Physiology, Molecular Biology, and Clinical Applications. New York: Humana Press; pp. 46994, 2010.

5- NEMATOLLAH S.A., MOHAMMAD R.T., FARHAD M. and MEHRDAD Z.: Vitamin D deficiency and psychological disorders. Journal of Parathyroid Disease, 2 (1): 21-5, 2014

6- JADDOU H.Y., BATIEHA A.M., KHADER Y.S., KANAAN S.H., EL-KHATEEB M.S. and AJLOUNI K.M.: Depression is associated with low levels of 25hydroxyvitamin D among Jordanian adults: Results from a national population survey. Eur. Arch. Psychiatry Clin. Neurosci., 262 (4): 321-7, 2012.

7- POLAK M.A., HOUGHTON L.A., REEDER A.I., MICHELLE J. HARPER M.J. and CONNER T.S.: Serum 25-Hydroxyvitamin D Concentrations and Depressive Symptoms among Young Adult Men and Women. Nutrients, 6: 4720-30, 2014

8- DANA-ALAMDARI L., KHEIROURI S. and NOORAZAR S.G.: Serum 25-Hydroxyvitamin D in Patients with Major Depressive Disorder. Iran J. Public Health, 44 (5): 690-7, 2015.

9- BECK A.T., STEER R.A. and BROWN G.K.: Manual for the Beck Depression Inventory, 2 nd ed. San Antonio, TX, 1996.

10- ANGLIN R.E., SAMAAN Z., WALTER S.D. and McDONALD S.D.: Vitamin D deficiency and depression in adults: Systematic review and meta-analysis. Br. J. Psychiatry, 202: 100-7, 2013.

11- FERNANDES De ABREU D.A., EYLES D. and FERON F.: Vitamin D, a neuroimmunomodulator: Implications for neurodegenerative and autoimmune diseases. Psychoneuroendocrinology, 34 (suppl 1): S265-277, 2009.

12- LANGLOIS K., GREENE-FINESTONE L., LITTLE J., HIDIROGLOU N. and WHITING S.: Vitamin D Status of Canadians as Measured in the 2007 to 2009 Canadian Health Measures Survey. Health Reports, 21 (1): 47-55, 2010.

13- SANG-HYUN K., HYUN S. and DONG S.K.: Relationship between serum Vitamin D levels and symptoms of depression in stroke patients. Ann. Rehabil. Med., 40 (1): 120-5, 2016.

14- HUSSEIN A., REDA I., HALA T., OMNIA A.A., RANIA H. and EMAN E.S.: Relationship between Depression and Low Vitamin D Level. J. Am. Sci., 9 (12): 979-83, 2013.

15- HILDEBRANDT M.G., STAGE K.B. and KRAGHSOERENSEN P.: Gender differences in severity, symptomatology and distribution of melancholia in major depression. Psychopathology, 36 (4): 204-12, 2003.

16- VON KÄNEL R., FARDAD N., STEURER N., HORAK N., HINDERMANN E., FISCHER F. and GESSLER K.: Vitamin D Deficiency and Depressive Symptomatology in Psychiatric Patients Hospitalized with a Current Depressive Episode: A Factor Analytic Study. PLoS One, 23, 10 (9): e0138550;1-15, 2015.

17- RYBA M.M. and HOPKO D.R.: Gender Differences in Depression: Assessing Mediational Effects of Overt Behaviors and Environmental Reward through Daily Diary Monitoring. Depress Res. Treat., 865679: 1-9, 2012.
18- TSOPELAS C., STEWART R., SAVVA G.M., et al.: Neuropathological correlates of late-life depression in older people. Br. J. Psychiatry, 198; 109-14, 2011.

19- MILANESCHI Y., SHARDELL M., CORSI A.M., VAZZANA R., BANDINELLI S., GURALNIK J.M. and FERRUCCI L.: Serum 25-hydroxyvitamin D and depressive symptoms in older women and men. J. Clin. Endocrinol. Metab., 95 (7): 3225-33, 2010.

20- KJÆRGAARD M., JOAKIMSEN R. and JORDE R.: Low serum 25-hydroxyVitamin D levels are associated with depression in an adult Norwegian population. Psychiatry Res., 190: 221-5, 2011.

21- MILANESCHI Y., HOOGENDIJK W., LIPS P., HEIJBOER A.C., SCHOEVERS R., VAN HEMERT A.M., BEEKMAN A.T., SMIT J.H. and PENN INX B.W.: The association between low Vitamin D and depressive disorders. Mol. Psychiatry, 19 (4): 444-51, 2014.

22- JORDE R., WATERLOO K., SALEH F., HAUG E. and SVARTBERG J.: Neuropsychological function in relation to serum parathyroid hormone and serum 25- hydroxyvitamin D levels. The Tromso study. J. Neurol., 253: 46470, 2006.

23- JORDE R., SNEVE M., FIGENSCHAU Y., SVARTBERG J. and WATERLOO K.: Effects of Vitamin D supplementation on symptoms of depression in overweight and obese subjects: Randomized double blind trial. J. Intern. Med., 264 (6): 599-609, 2008.

24- KJAERGAARD M., WATERLOO K. and WANG K.: Effects of vitamin D supplement on depression scores in people with low levels of serum 25-hydroxyvitamin D: Nested case-control study and randomised trial. Br. J. Psychiatry. The British Journal of Psychiatry: The Journal of Mental Science, 201 (5); 360-8, 2012.

25- BERTONE-JOHNSON E.R.: Vitamin D and the occurrence of depression: Causal association or circumstantial evidence? Nutr. Rev., 67 (8): 481-92, 2009.

26- WALBERT T., JIRIKOWSKI G.F. and PRÜEFER K.: Distribution of 1,25-dihydroxyvitamin D3 receptor immunoreactivity in the limbic system of the rat. Horm. Metab. Res., 33: 525-31, 2001.

27- GANJI V., MILONE C., CODY M.M., McCARTY F. and WANG Y.T.: Serum vitamin D concentrations are related to depression in young adult US population: The Third National Health and Nutrition Examination Survey. Int. Arch. Med., 11, 3: 29, 2010.

28- ALMERAS L., EYLES D., BENECH .P, LAFFITE D., VILLARD C., PATATIAN A., BOUCRAUT J., MACKAY-SIM A., McGRATH J. and FERON F.: Developmental vitamin deficiency alters brain protein expression in the adult rat: Implications for neuropsychiatric disorders. Proteomics, (7): 769-80, 2007.

29- NEWMARK H. and NEWMARK J.: Vitamin D and Parkinson's disease-A hypothesis. Movement Disorder Society, 22: 461-8, 2007.

30- MILLER H.M., MALETIC V. and RAISON C.L.: Inflammation and its discontents: The role of cytokines in the pathophysiology of major depression. Biol. Psychiatry, 65: 732-41, 2009.

31- NANRI A., MIZOUE T., MATSUSHITA Y., POUDELTANDUKAR K., SATO M., OHTA M. and MISHIMA 
N.: Association between serum 25-hydroxyvitamin D and depressive symptoms in Japanese: Analysis by survey season. Eur. J. Clin. Nutr., 63: 1444-7, 2009.

32- HOOGENDIJK W.J., LIPS P., DIK M.G., DEEG D.J., BEEKMAN A.T.F. and PENNINX B.W.J.: Depression is associated with decreased 25-hydroxyvitamin D and increased parathyroid hormone levels in older adults. Arch. Gen. Psychiatry, 65: 508-12, 2008.

33- ALLALI F., EL AICHAOUI S., KHAZANI H., BENYAHIA B., SAOUD B., EL KABBAJ S., BAHIRI R., ABOUQAL R. and HAJJAJ-HASSOUNI N.: High prevalence of hypovitaminosis D in Morocco: Relationship to lifestyle, physical performance, bone markers, and bone mineral density. Semin. Arthritis Rheum., (38): 444-51, 2009.

34- BARONCELLI G., BEREKET A., EL-KHOLY M., et al.: Rickets in the Middle East: Role of environment and genetic predisposition. J. Clin. Endocrinol. Metab., (93): 1743-50, 2008.

35- ZHAO G., FORD E.S., LI C. and BALLUZ L.S.: No associations between serum concentrations of 25- hydroxyvitamin $\mathrm{D}$ and parathyroid hormone and depression among US adults. Br. J. Nutr., 201-7, 2010.

36- PAN A., LU L., FRANCO O.H., YU Z., LI H. and LIN X.: Association between depressive symptoms and 25hydroxyvitamin D in middle-aged and elderly Chinese. J. Affect. Disord., 118 (1-3): 240-3, 2009.

37- LEE D.M., TAJAR A., O'NEILL T.W., O'CONNOR D.B., BARTFAI G., BOONEN S., BOUILLON R., CASANUEVA F.F., FINN J.D., FORTI G., GIWERCMAN A., HAN T.S., HUHTANIEMI I.T., KULA K., LEAN M.E., PUNAB M., SILMAN A.J., VANDERSCHUEREN D., WU F.C., PENDLETON N. and EMAS STUDY GROUP: Lower Vitamin D levels are associated with depression among community-dwelling European men. J. Psychopharmacol., 25 (10): 1320-8, 2011.

38- HOANG M.T., DeFINA L.F., WILLIS B.L., et al.: Association between low serum 25-hydroxyVitamin D and depression in a large sample of healthy adults: The Cooper Center Longitudinal Study. Mayo. Clin. Proc., 86: 1050$5,2011$.

\section{مستوى فيتامين د فى مرضى الإكتئاب}

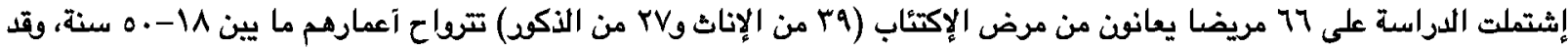

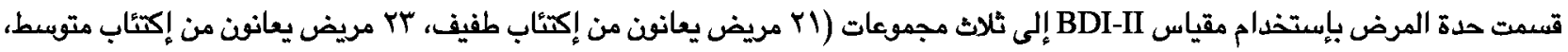

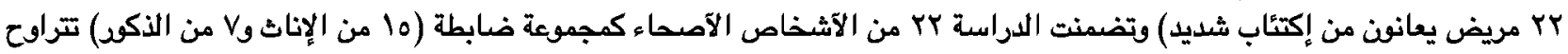

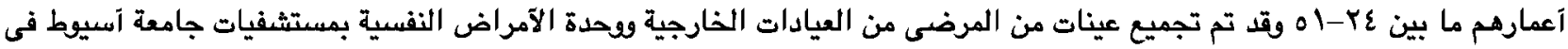

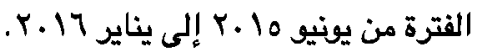

$$
\begin{aligned}
& \text { وتم عمل الآثى لكل من المرضى والآشّخاص الآصساء: } \\
& \text { - التاريخ المرضى. } \\
& \text { - الفحص الإكلينيكى. } \\
& \text { - الفحوصات المعملية: }
\end{aligned}
$$

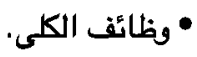

$$
\begin{aligned}
& \text { • وظائف كبد كاملة. } \\
& \text { • مستوى الكالسيوم، والفوسيفو. } \\
& \text { • مستوى فيتامين (د). }
\end{aligned}
$$

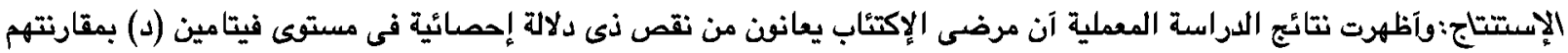

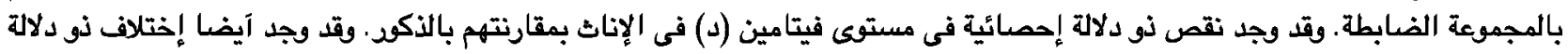

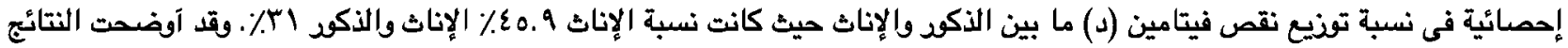

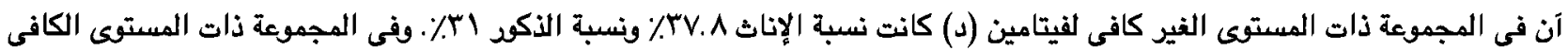

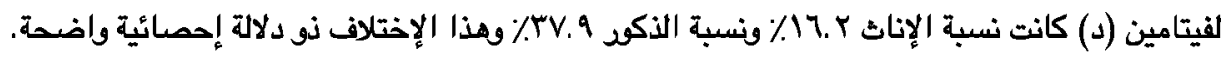

كا ن هناك إختلاف ذو دلالة إحصائية بين المجموعات الثلاث من الإكتئاب (الطفيف، المتوسط والشديد) حيث آن آنقائل آتل مستوى الفيتامين

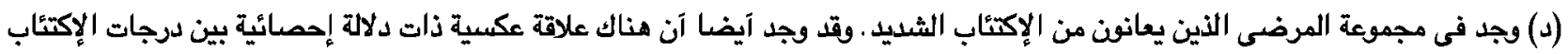

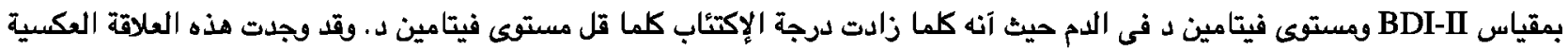

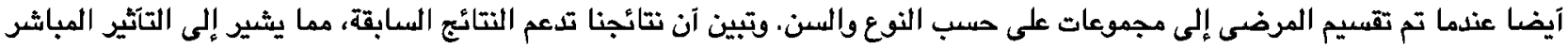

